(Uniwersytet im. Adama Mickiewicza, Poznań,

e-mail: asselsagimbekova@gmail.com)

ORCID: 0000-0002-9774-6145

Pamięci Profesora Tadeusza Zgółki poświęcam

\title{
PROBLEMY I PERSPEKTYWY PRZEJŚCIA JĘZYKA KAZACHSKIEGO NA ALFABET LACIŃSKI
}

Kwestia przejścia języka kazachskiego na alfabet łaciński jest omawiana w Kazachstanie od ponad 30 lat. Jeśli jednak przedtem ten temat był podejmowany sporadycznie, bez jakichkolwiek konkretnych kroków w tym kierunku, to od 2017 roku Kazachstan podjał praktyczne działania w zakresie zmiany alfabetu.

26 października 2017 roku Prezydent Kazachstanu Nursułtan Nazarbajew podpisał dekret nr 569 O przejściu języka kazachskiego na alfabet łacinski. ${ }^{1}$ Zgodnie $z$ postanowieniami tego dekretu utworzono wówczas Komisję Narodową ds. Przejścia Języka Kazachskiego na Alfabet Łaciński, a także opracowano etapowy plan działań w zakresie przejścia języka kazachskiego na alfabet łaciński do 2025 roku.

Utworzono 4 grupy robocze do spraw: wsparcia ortograficznego, metodycznego, terminologicznego oraz technicznego i informacyjnego. Grupa ortograficzna opracowała Nowe zasady ortografii języka kazachskiego. ${ }^{2}$ Ponadto podjęto szereg działań mających na celu wdrożenie nowego alfabetu do przestrzeni informacyjnej.

To, o czym lingwiści mówili jeszcze w roku 1989, kiedy została przyjęta Ustawa o językach $w$ Kazachskiej $S R R,{ }^{3}$ zaczęto wdrażać dopiero w 2017 roku. Jako jeden $z$ pierwszych o przejściu na łaciński alfabet zaczął mówić i pisać kazachski językoznawca, turkolog i działacz spo-

1 Qazaq tili álipbiin kirıllıtsadan latyn grafikasyna kóshirý týraly, oficjalna strona Prezydenta Republiki Kazachstanu, 27 października 2017 [dostęp: 14 lutego 2021]. Dostępny w Internecie: https://www.akorda.kz/kz/legal_acts/decrees/kazak-tili-alipbiin-kirillicadan-latyn-grafikasyna-koshiru-turaly

2 Emle erejeleri, strona internetowa Narodowego centrum Naukowo-Praktycznego im. Sz. Szajachmetowa „Til-Qazyna” [dostęp: 14 lutego 2021]. Dostępny w Internecie: https:/ /www.qazlatyn.kz/grammar

3 Zakon Kazahskoj Sovetskoj Socialističeskoj Respubliki ot 22 sentjabrja 1989 goda O jazykah v Kazahskoj SSR, [dostęp: 14 lutego 2021]. Dostępny w Internecie: https:// online.zakon.kz/document/?doc_id=1005765\#pos=15;-116 
łeczny Abduali Kajdarow. W 1992 roku Kajdarow wziął udział w Kongresie Turkologicznym, na który zostali zaproszeni przedstawiciele ludów tureckich byłego ZSRR. Jednym $z$ głównych tematów tego spotkania była zmiana grafii języków narodów tureckich na alfabet łaciński. Po powrocie $z$ Kongresu uczony napisał list otwarty do prezydenta Nazarbajewa, w którym uzasadnił, dlaczego język kazachski trzeba przenieść do strefy alfabetu łacińskiego, wysłał opracowaną przez siebie koncepcję i zaproponował pierwszy projekt kazachskiego alfabetu opartego na łacińskim. Propozycja A. Kajdarowa spotkała się z dużym zainteresowaniem naukowców i całego społeczeństwa Kazachstanu. Jednak, jak podkreślał uczony, potrzebna była w tej sprawie decyzja polityczna. Prezydent Nazarbajew poruszal tę kwestię w roku 1995 oraz 2006 na posiedzeniu Zgromadzenia Narodu Kazachstanu (jest to organ konsultacyjno-doradczy głowy państwa, reprezentujący interesy narodów zamieszkujących Republikę Kazachstanu), ale dokładnej daty wówczas nie ustalono. Dopiero w 2012 roku w Orędziu Prezydenta Republiki Kazachstanu Nursuttana Nazarbajewa do narodu Kazachstanu „Strategia "Kazachstan-2050": nowy kurs polityczny dla umocnionego państwa" została ustalona data przejścia na alfabet łaciński - poczynając od 2025 roku język kazachski $z$ mieni grafię $z$ cyrylicy na alfabet łaciński. ${ }^{4}$ Warto nadmienić, iż prezydent wskazuje tę datę również jako datę graniczną wyznaczoną obywatelom Kazachstanu do opanowania przez nich języka kazachskiego.

Naukowcy od razu sięgnęli do historii języka kazachskiego, który był zapisywany trzema różnymi alfabetami. Aż do początku XX wieku Kazachowie używali alfabetu arabskiego. W 1912 roku uznany kazachski językoznawca, literaturoznawca, poeta i działacz państwowy Achmet Bajtursynuly zreformował istniejacy alfabet, upraszczając go $z$ uwzględnieniem osobliwości fonetycznych języka kazachskiego. Ten nowy alfabet nazwano mome жазу, czyli proste pismo. Korzystaja $z$ niego do tej pory Kazachowie mieszkajacy w Chinach, Afganistanie oraz Iranie. W roku 1929 dokonano reformy i zmieniono alfabet na łaciński, gdyż uznano, że alfabet arabski hamuje rozwój Kazachstanu. Nowy alfabet składał się z 29 liter i był stosowany stosunkowo krótko - do roku 1939. Największym przeciwnikiem latynizacji był Achmet Bajtursynuly, który uważał arabski alfabet za bardziej dostosowany do zapisywania kazachskich głosek. Natomiast największym zwolennikiem łacińskiego alfabetu był lingwista, turkolog, tłumacz Tielżan Szonanuly, który widział w arabskim alfabecie szereg wad, w tym m.in. użycie znaków diakrytycznych. W roku 1940 dokonano przejścia na cyrylicę. Alfabet języka kazachskiego oparty

4 N. Nazarbaev, Poslanie Prezidenta Respubliki Kazahstan - Lidera Nacii N.A.Nazarbaeva Narodu Kazahstana "Strategija „Kazahstan-2050”: Novyj političeskij kurs sostojavšegosja gosudarstva”, 14 grudnia 2012 [dostęp: 14 lutego 2021]. Dostępny w Internecie: https://online.zakon.kz/m/document/?doc_ id=31305418\#sub_id=70300 
na cyrylicy składał się z 42 liter i jest stosowany do dzisiaj. Zaproponował ten alfabet kazachski językoznawca, turkolog Sarsen Amanżołuly.

\begin{tabular}{|c|c|c|c|c|c|c|}
\hline Аа & Әә & Бб & Вв & Гг & Ғғ & Дд \\
\hline Ее & Ё̈ & Жж & Зз & Ии & Йй & Кк \\
\hline Қк & Лл & Мм & Нн & Нн & Оо & Өө \\
\hline Пп & Рр & Сс & Тт & Уу & Ұ & ҮҮ \\
\hline ФФ & $\mathrm{Xx}$ & Һһ & Цц & Чч & Шш & Щщ \\
\hline Һъ & Ыы & Іі & ьь & Ээ & Юю & Яя \\
\hline
\end{tabular}

Źródło: opracowanie własne.

Widzac w ponownym zastosowaniu łacińskiego alfabetu szereg pożytków dla rozwoju języka i kraju, Nursułtan Nazarbajew - pierwszy prezydent Republiki Kazachstanu - w swoim artykule $z$ dnia 12 kwietnia 2017 roku Spojrzenie w przyszłość: modernizacja świadomości społecz$n e j^{5}$ zaproponował, aby jak najszybciej omówić problemy związane $z$ alfabetem kazachskim i do końca 2017 roku zatwierdzić nowy jego wariant.

Opracowano wówczas kilka projektów. Jako pierwszy 11 września 2017 roku zaproponowano wstępnie alfabet, który składał się z 25 liter alfabetu łacińskiego. ${ }^{6}$ Niektóre kazachskie litery zaś miały być zapisywane za pomoca ośmiu dwuznaków (o-ae, $\theta-o e, Y-u e, \mu-n g, z-g h$, $u-c h, u-s h, ж-z h$ ). Następnie, 9 października 2017 roku, zaproponowano projekt alfabetu składającego się z 32 liter, który został opublikowany oficjalnie jako załącznik do dekretu nr 569. Zaproponowano, by osiem kazachskich liter zapisywać $z$ apostrofem, a litery $u, \breve{u}$ zapisywać za pomoca łacińskiej litery $i$.

5 N. Nazarbaev, Memleket basshysynyń „Bolashaqqa baǵdar: rýhanı jańǵyrý” atty maqalasy, 12 kwietnia 2017 [dostęp: 14 lutego 2021]. Dostępny w Internecie: https://www.akorda.kz/kz/events/akorda_news/press_conferences/memleket-basshysynyn-bolashakka-bagdar-ruhani-zhangyru-atty-makalasy

6 Zh. Urankaeva, Predvaritel'nyj alfavit kazahskogo jazyka na latinice, 11 września 2017 [dostęp: 14 lutego 2021]. Dostępny w Internecie: https:// www.kazpravda.kz/news / obshchestvo/predvaritelnii-alfavit-kazahskogoyazika-na-latinitse 


\begin{tabular}{|c|c|c|c|c|c|}
\hline № & Жазылуы & Дыбысталуы & № & Жазылуы & Дыбысталуы \\
\hline 1 & $\mathbf{A} \mathbf{a}$ & [a] & 17 & $\mathbf{N}^{\prime} \mathbf{n}^{\prime}$ & [н], [нг] \\
\hline 2 & $\mathbf{A}^{\prime} \mathbf{a}^{\prime}$ & [ə] & 18 & $\mathbf{O}_{0}$ & [0] \\
\hline 3 & B b & [б] & 19 & O' o' & [ө] \\
\hline 4 & D d & [д] & 20 & $\mathbf{P} \mathbf{p}$ & [ח] \\
\hline 5 & E e & [e] & 21 & $\mathbf{Q q}$ & [k] \\
\hline 6 & F f & [ф] & 22 & $\mathbf{R} \mathbf{r}$ & [p] \\
\hline 7 & G g & {$[\boldsymbol{\Gamma}]$} & 23 & $\mathbf{S} \mathbf{s}$ & [c] \\
\hline 8 & G' g' & [F] & 24 & S' s' & [III] \\
\hline 9 & H h & {$[\mathbf{x}],[\mathbf{h}]$} & 25 & $C^{\prime} c^{\prime}$ & [ч] \\
\hline 10 & I i & [i] & 26 & $\mathbf{T t}$ & [T] \\
\hline 11 & I'i' & [и], [й] & 27 & $\mathbf{U} \mathbf{u}$ & [¥] \\
\hline 12 & $\mathbf{J} \mathbf{j}$ & [ж] & 28 & U' u' & [Y] \\
\hline 13 & $\mathbf{K} \mathbf{k}$ & [к] & 29 & $\mathbf{V} \mathbf{v}$ & [B] \\
\hline 14 & L I & [л] & 30 & $\mathbf{Y y}$ & [ы] \\
\hline 15 & M m & [M] & 31 & $Y^{\prime} \mathbf{y}^{\prime}$ & [y] \\
\hline 16 & $\mathbf{N} n$ & {$[\mathbf{H}]$} & 32 & $\mathbf{Z}_{\mathbf{z}}$ & [3] \\
\hline
\end{tabular}

Źródło: http://www.akorda.kz/kz

Obydwa projekty nie zyskały akceptacji ze strony społeczeństwa. Mieszkańcy Kazachstanu uznali propozycje nowych alfabetów za mało praktyczne i niedopasowane do specyfiki kazachskiej fonetyki. 19 lutego 2018 roku prezydent zatwierdził nowy projekt kazachskiego alfabetu opartego na łacińskim uzupełnionym o znaki diakrytyczne - oznaczające akcent ostry akutowy. ${ }^{7} \mathrm{Z}$ akcentem ostrym w nowym alfabecie zapisy-

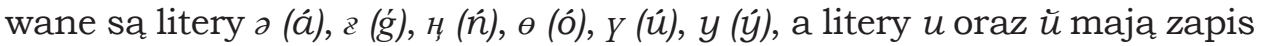
w postaci litery $\imath$ (bez kropki). Dodano także dwa dwuznaki sh zamiast $u$ oraz ch zamiast $u$.

7 „Qazaq tili álipbiin kirillttsadan latyn grafikasyna kóshirý týraly” Qazaqstan Respýblıkasy Prezıdentinin 2017 jylǵy 26 qazandaǵy №569 Jarlyǵyna ózgeris engizý týraly, 20 lutego 2018 [dostęp: 14 lutego 2021]. Dostępny w Internecie: https://www.akorda.kz/kz/legal_acts/decrees/kazak-tili-alipbiin-kirillicadanlatyn-grafikasyna-koshiru-turaly-kazakstan-respublikasy-prezidentinin-2017zhylgy-26-kazandagy-569-zharlygy 


\begin{tabular}{|c|c|c|c|c|c|}
\hline № & Жазылуы & Дыбысталуы & № & Жазылуы & Дыбысталуы \\
\hline 1 & A a & [a] & 17 & Ń ń & [H] \\
\hline 2 & Á á & [ə] & 18 & O o & [0] \\
\hline 3 & B b & [б] & 19 & Ó ó & {$[\theta]$} \\
\hline 4 & D d & [д] & 20 & $\mathbf{P} \mathbf{p}$ & [II] \\
\hline 5 & $\mathbf{E} \mathbf{e}$ & [e] & 21 & $\mathbf{Q} \mathbf{q}$ & {$[\mathbf{k}]$} \\
\hline 6 & F f & [Ф] & 22 & $\mathbf{R} \mathbf{r}$ & [p] \\
\hline 7 & G $\mathbf{g}$ & [r] & 23 & S s & [c] \\
\hline 8 & Ǵ $\mathbf{g}$ & [F] & 24 & $\mathbf{T t}$ & [T] \\
\hline 9 & $\mathbf{H ~ h}$ & {$[\mathbf{x}],[\mathbf{h}]$} & 25 & $\mathbf{U} \mathbf{u}$ & [¥] \\
\hline 10 & I i & [i] & 26 & Ú ú & [Y] \\
\hline 11 & I 1 & [и], [й $]$ & 27 & $\mathbf{V} \mathbf{v}$ & [B] \\
\hline 12 & $\mathbf{J} \mathbf{j}$ & {$[\%]$} & 28 & $\mathbf{Y y}$ & [ы] \\
\hline 13 & $\mathbf{K} \mathbf{k}$ & [K] & 29 & $\dot{\mathbf{Y}} \mathbf{y}$ & [y] \\
\hline 14 & L 1 & [л] & 30 & $\mathbf{Z ~ z}$ & [3] \\
\hline 15 & M m & [M] & 31 & Sh sh & [m] \\
\hline 16 & N n & [н] & 32 & Ch ch & {$[\Psi]$} \\
\hline
\end{tabular}

Źródło: http:/ / www.akorda.kz/kz

21 października 2019 roku obecny prezydent Kazachstanu Kasym-Żomart Tokajew polecił udoskonalić zatwierdzony w 2018 roku alfabet. 28 stycznia 2021 roku Narodowa Komisja ds. Przejścia Języka Kazachskiego na Alfabet Łaciński przedstawiła kolejny, ulepszony wariant alfabetu języka kazachskiego składający się z 31 liter. ${ }^{8}$ Dokonano kilku znaczacych zmian, a mianowicie: usunięto dwuznaki, ale dodano takie znaki diakrytyczne jak umlaut - $\ddot{a}, \ddot{o}, \ddot{u}$, brewis - $\breve{g}$, makron - $\bar{u}$ oraz cedylla - ş. Alfabet opracowano zgodnie $z$ zasada „jedna głoska - jedna litera”. Kolejny etap przejścia zaplanowano na lata 2023-2031.

8 Kogda načnetsja perehod na novyj alfavit v Kazahstane, gazeta „Kazahstanskaja Pravda”, 28 stycznia 2021 [dostęp: 14 lutego 2021]. Dostępny w Internecie: https://www.kazpravda.kz/news/obshchestvo/predstavlen-obnovlennii-alfavitkazahskogo-yazika-na-latinitse 


\section{ЖАНА КАЗАК ӘЛІІБИІ}

\begin{tabular}{|c|c|c|c|c|c|c|c|}
\hline No & латынша & кирилше & әріптің атауы & № & латынша & кирилше & әріптің атауы \\
\hline 1 & A a & A a & $a$ & 18 & $\mathrm{O}_{0}$ & O o & $o$ \\
\hline 2 & $\ddot{\mathbf{A}} \mathbf{a}$ & Әə & a & 19 & Ö ö & $\theta_{\theta}$ & $\theta$ \\
\hline 3 & B b & Б б & бы & 20 & $\mathbf{P p}_{\mathbf{p}}$ & $\Pi \pi$ & пы \\
\hline 4 & D d & Дд & $\partial ы$ & 21 & $\mathbf{Q q}$ & Қк & қы \\
\hline 5 & $\mathbf{E} \mathbf{e}$ & $\mathrm{E} \mathrm{e}$ & $e$ & 22 & $\mathbf{R} \mathbf{r}$ & $\mathrm{Pp}$ & ыр \\
\hline 6 & F f & $\Phi \Phi$ & $\phi ы$ & 23 & S s & $\mathrm{Cc}$ & $c b l$ \\
\hline 7 & $\mathbf{G} \mathbf{g}$ & $\Gamma \Gamma$ & $2 i$ & 24 & Ş ş & Ш ш & шы \\
\hline 8 & $\check{\mathbf{G}} \check{\mathbf{g}}$ & $\digamma_{F}$ & $8 b$ & 25 & T t & $\mathrm{T} T$ & $m b l$ \\
\hline 9 & H h & $\mathrm{X} \mathrm{x}, \mathrm{Hh}$ & $h b$ & 26 & $\mathbf{U} \mathbf{u}$ & y y & $\not y$ \\
\hline 10 & İi & Й й, И и & iŭ & 27 & $\overline{\mathbf{U}} \overline{\mathbf{u}}$ & $¥ ¥$ & $y$ \\
\hline 11 & I & I i & $i$ & 28 & $\ddot{\mathbf{U}} \ddot{\mathbf{u}}$ & $\mathrm{YY}_{Y}$ & $Y$ \\
\hline 12 & $\mathbf{J} \mathbf{j}$ & Жж & Жы & 29 & $\mathbf{V} \mathbf{v}$ & B в & $8 b$ \\
\hline 13 & $\mathbf{K ~ k}$ & K K & $\kappa i$ & 30 & $\mathbf{Y y}$ & Ыы & $b l$ \\
\hline 14 & L I & Л л & bыл & 31 & $\mathbf{Z}_{\mathbf{z}}$ & 33 & $3 ы$ \\
\hline 15 & M m & $\mathrm{M} \mathrm{M}$ & мы & & \multirow{3}{*}{\multicolumn{3}{|c|}{$\begin{array}{r}{ }^{*} \mathrm{C}, \mathrm{X}, \mathrm{W} \text { таңбалары цитаталық прннцнптен жазылатын } \\
\text { шеттілдік сөздерде қолданылады. }\end{array}$}} \\
\hline 16 & N n & $\mathrm{H} \mathrm{н}$ & ны & & & & \\
\hline 17 & $\mathbf{D}$ n & Нн & ың & & & & \\
\hline
\end{tabular}

Źródło: https://www.kazpravda.kz/

Mimo że do tej pory nie zatwierdzono ostatecznie wariantu alfabetu, mieszkańcy Kazachstanu już od momentu przedstawienia pierwszych wersji alfabetu zaczęli ich aktywnie używać, szczególnie zapisu języka kazachskiego opartego na alfabecie łacińskim $z$ akcentem ostrym. Można to zaobserwować na kazachskojęzycznych szyldach i banerach reklamowych, w korespondencji w Internecie, na tablicach $z$ nazwami ulic w szeregu kazachstańskich miast, a nawet w dokumentach urzędowych. ${ }^{9}$ Ponadto, wiosna 2019 roku wprowadzono do obiegu nowe monety, na których wykonano napis alfabetem łacińskim. ${ }^{10}$ Nowy napis - w alfabecie łacińskim - ma również godło Republiki Kazachstanu. ${ }^{11}$ Warto również wspomnieć o tym, iż od końca 2018 roku wydawana jest kazachskoję-

9 Činouniki stali otvečat' na obraščenija graždan na latinice, portal zakon. kz, 2 listopada 2017 [dostęp: 14 lutego 2021]. Dostępny w Internecie: https:// www.zakon.kz/4886650-chinovniki-stali-otvechat-na.html

10 E. Eliseeva, V Kazahstane vypustili $v$ obraščenie obnovlennye monety s nadpis'ju "QAZAQSTAN”, gazeta „Kazahstanskaja Pravda”, 26 kwietnia 2019 [dostęp: 14 lutego 2021]. Dostępny w Internecie: https://kazpravda.kz/news/ ekonomika/v-kazahstane-vipustili-v-obrashchenie-obnovlennie-moneti-snadpisu-qazaqstan

11 Qazaqstan Respýblikasynyń memlekettik eltańbasy, oficjalna strona Prezydenta Republiki Kazachstanu [dostęp: 14 lutego 2021]. Dostępny w Internecie: https://www.akorda.kz/kz/state_symbols/kazakhstan_emblem 
zyczna gazeta Til-Qazyna, która używa wariantu alfabetu $z$ akcentem ostrym akutowym. ${ }^{12}$

Dotychczasowe warianty alfabetu nie przyjęły się z kilku przyczyn. Zatwierdzony w 2018 roku przez prezydenta Nazarbajewa alfabet $z$ akcentem akutowym, który dotychczas był najczęściej używany przez użytkowników języka kazachskiego, stwarzał szereg problemów o charakterze technicznym. Konwertery, w tym opracowany przez Instytut Naukowo-Badawczy „Til Qazyna” konwerter qazlatyn.kz, nie rozpoznaja niektórych znaków nowego alfabetu. Problemów przysparzają dwuznaki ch i sh oraz wielka litera I, która zastępuje kilka liter kazachskiego alfabetu $u, \check{u} \operatorname{oraz} i$. Konwerter rozpoznaje dwuznaki ch i sh jako osobne litery. Przeprowadzone do tej pory sondaże pokazuja, że także przeciętni użytkownicy języka kazachskiego maja problem $z$ odczytywaniem dwuznaku sh. Zapisany łacińskim alfabetem wyraz arzыcxam (alǵyshat) 'list dziękczynny, pismo z podziękowaniem' - niektóre osoby przeczytały jako arzыщam (polska transkrypcja: ałgyszat), czyli odczytały często spotykane w kazachskich wyrazach litery $s$ i $h$ stojacce obok siebie, ale wymawiane osobno jako głoski [s] i [h], razem jako głoskę [sz]. Dotyczy to szczególnie osób, które nie znają wystarczająco dobrze języka kazachskiego, zwłaszcza w wersji pisanej, albo dopiero się go ucza. Większość respondentów miała kłopot $z$ odróżnieniem wielkich liter $И(I)$ oraz $I(I)$, które w wersji pisanej wyglądają identycznie, a oznaczają dwie różne głoski, np. Ishik (imik) - 'futro' - oraz Ine (uнe) - 'igła'. Kazachskie litery zapisywane jako b oraz $y$ w łacińskiej wersji zapisywane sa odpowiednio jako $y$ oraz $\dot{y}$, czyli sa graficznie bardzo podobne i często użytkownicy języka myla te litery. Tak na przykład wygląda zapis wyrazu aybuл - 'wieś' - według nowego alfabetu aýyl. ${ }^{13}$ Lingwiści sa zaniepokojeni tym, że przyszłe pokolenia użytkowników języka kazachskiego po dokonaniu zmiany na alfabet łaciński będą nieprawidłowo wymawiać kazachskie wyrazy, czyli że zmiana grafii spowoduje zmiany także w kazachskiej fonetyce. Dlatego naukowcy kontynuuja prace nad ulepszaniem alfabetu, uwzględniając nie tylko aspekty językowe, ale również techniczne. Ostatni projekt alfabetu - zaproponowany w styczniu 2021 roku - przedstawiono już wraz z układem klawiszy na klawiaturze komputerowej.

Niemniej jednak nowy projekt alfabetu, mimo iż został opracowany z uwzględnieniem wcześniejszych komentarzy językoznawców i opinii społecznej użytkowników języka kazachskiego, znowu wywołał ne-

12 „Til-Qazyna” Respýblıkalyq aqparattyq-tanymdyq gazeti [dostęp: 14 lutego 2021]. Dostępny w Internecie: https:/ / gazet.tilqazyna.kz/pdf

${ }^{13}$ E. Kazistaev, Zh. Habdulhabar, Net digrafov, est' umlaut, brevis i sedil'. Kak predlagajut menjat' novyj kazahskij alfavit na latinice, portal informacyjny informburo.kz, 14 listopada 2019 [dostęp: 14 lutego 2021]. Dostępny w Internecie: https://informburo.kz/stati/net-digrafov-est-umlaut-brevis-i-sedil-kakpredlagayut-menyat-novyy-kazahskiy-alfavit-na-latinice.html 
gatywne reakcje wśród Kazachstańczyków. Dużo wątpliwości budzi wprowadzony nowy znak $\eta$, który zastapi literę $\mu \underline{\mathrm{w}}$ alfabecie opartym na cyrylicy. Dyrektor Instytutu Badań Współczesnych Euroazjatyckiego Uniwersytetu Narodowego im. L.N. Gumilowa w Nur-Sułtanie, doktor nauk filologicznych Muchit-Ardagier Sydyknazarow uważa, że wprowadzenie takiego znaku, który jest obecny w alfabecie greckim (litera „eta”), a także w międzynarodowym alfabecie fonetycznym, jest dużym błędem. Ekspert podkreśla, że wprowadzanie dodatkowych znaków, nieobecnych w łacińskim alfabecie, absolutnie nie ma sensu i jest zwolennikiem „czystego łacińskiego alfabetu”, bo, jak podkreśla, „przejdziemy z quasi-cyrylicy na quasi-łacinke”. ${ }^{14} \mathrm{~W}$ Internecie rozgorzała ostra dyskusja na temat tej wersji alfabetu. Pisarz i popularyzator języka kazachskiego Kanat Tasibekow proponuje zatem zastapić $\not$ dwuznakiem $n g$, a większość internautów proponuje wrócić do ń $z$ akutem.

Od 2017 roku zaproponowano kilka wariantów alfabetu języka kazachskiego, ale wydaje się, że żaden $z$ nich nie jest odpowiedni do zatwierdzenia i wdrożenia.

Opinie na temat przejścia języka kazachskiego na alfabet łaciński sa bardzo różne. Wypowiadaja się na ten temat nie tylko językoznawcy, ale również politycy, działacze społeczni i całe społeczeństwo Kazachstanu. Socjologowie niejednokrotnie przeprowadzali badania majace na celu poznanie opinii społecznej na temat zmiany alfabetu. Jedno $z$ najnowszych badań zostało przeprowadzone tuż po podpisaniu dekretu o przejściu na alfabet łaciński w ramach projektu „Społeczno-polityczne aspekty przejścia języka kazachskiego na alfabet łaciński” Instytutu Filozofii, Politologii i Religioznawstwa Komitetu Nauki Ministerstwa Nauki i Edukacji Republiki Kazachstanu. ${ }^{15}$ Badanie $z$ zastosowaniem metody zogniskowanego wywiadu grupowego zostało przeprowadzone w sześciu regionach $\mathrm{Ka}$ zachstanu: Nur-Sułtanie (obecna nazwa stolicy Kazachstanu), Kyzyłordzie, Pawłodarze, Tarazie i w dwóch obwodach: północnokazachstańskim i ałmackim. Większość respondentów wyraziła poparcie dla tej inicjatywy, co można uznać za argument na rzecz uznania, że proces przejścia rozpoczęto we właściwym czasie. Respondenci widza także korzyści i nowe możliwości komunikacyjne, które ta reforma ze sobą niesie. Mniejsza część respondentów - głównie są to osoby rosyjskojęzyczne, przedstawiciele słowiańskich grup etnicznych, ludzie w średnim i podeszłym wieku - wyraziła obawy w związku ze zmianą alfabetu. Wśród argumentów wymieniano m.in. to, że teraz nie jest właściwy czas na takie zmiany, że pod względem

14 M. Sydyknazarov, Esli delat' - tak čisto!, oficjalna strona Instytutu Językoznawstwa im. Achmeta Bajtursynuly [dostęp: 14 lutego 2021]. Dostępny w Internecie: https://tbi.kz/opinions

15 D. Ešpanova, R. Kadyržanov, Perevod kazahskoj pis'mennosti na latinskuju grafiku glazami kazahstancev, „Al-Farabi. Journal of socio-humanitarian studiues" 2017, nr 4 (60), s. 15-24. 
gospodarczym i finansowym jest to przedsięwzięcie nieracjonalne, a także że sprawi ono trudności osobom starszym, którym łaciński alfabet nie jest znany. Niewielka grupa badanych zajęła pozycję neutralną (są to głownie osoby, które nie mają wystarczającej wiedzy na ten temat).

Wśród korzyści spodziewanych po przejściu na alfabet łaciński badani wymienili następujące:

- szybsza integracja Kazachstanu z zachodnioeuropejska społecznościa międzynarodowa;

- $\quad$ zbliżenie się $z$ narodami tureckimi;

- wzrost atrakcyjności kraju dla cudzoziemców;

- ważny krok ku dalszemu wzmocnieniu niepodległości i konsolidacji narodu;

- modernizacja kraju;

- odrodzenie kodu kulturowego.

Jako obawy wymieniono kwestie następujące:

- niechęć wobec jakichkolwiek zmian;

- brak motywacji do uczenia się nowego alfabetu;

- brak bazy metodycznej;

- zbyt szybkie tempo wdrażania;

- duże koszty finansowe tego przedsięwzięcia;

- możliwe odejście uczniów ze szkół kazachskich do rosyjskich;

- możliwa emigracja kadry wykształconej (drenaż mózgów).

Opinia społeczna jeszcze się kształtuje, a społeczność i naukowcy intensywnie omawiaja pozytywne i negatywne aspekty zmiany alfabetu.

Językoznawcy w tej kwestii wypowiadaja się bardzo aktywnie. Przejście na łaciński alfabet uzasadniaja przede wszystkim tym, że dokładnie oddaje on system fonetyczny języka kazachskiego. Obecnie alfabet języka kazachskiego oparty na cyrylicy składa się z 42 liter - 33 litery rosyjskiego alfabetu plus 9 specyficznych liter kazachskich. System fonetyczny języka kazachskiego natomiast liczy tylko 28 głosek. Co do zasady powinno być odwrotnie. Tak, jak jest to w większości języków. Przejście na alfabet łaciński oznaczałoby więc zgodność liter i głosek. Wśród najważniejszych argumentów wymieniane jest również wzmocnienie tożsamości narodowej narodu kazachskiego. Jak pokazuje historia, pismo ma równie ważne znaczenie dla kształtowania się tożsamości narodowej co język (tak jest w wypadku Chińczyków, Arabów, Gruzinów i innych narodów). To, w jaki sposób język jest zapisywany, stanowi element wyrażania swojej tożsamości. Kazachowie należa do nielicznych społeczeństw wśród narodów tureckich, które jeszcze nie przeszły na alfabet łaciński. Obecnie Kazachstan ma możliwość wykorzystania doświadczenia Turcji, Uzbekistanu, Azerbejdżanu, by zmienić swój alfabet bez większych strat. Często podkreślana jest także możliwość integracji ze światową społecznościa oraz łatwiejsza praca w Internecie.

Jednak sa tacy (jest ich stosunkowo niewielu), którzy uważaja, że wystarczy modernizacja alfabetu opartego na cyrylicy, a dokładniej - 
usunięcie niektórych liter alfabetu rosyjskiego. ${ }^{16} \mathrm{~A}$ więc bez szkody dla pisma kazachskiego można usunąć b i b (miękki i twardy znak), a zapożyczenia rosyjskie, w których te litery występuja, można dostosować do zasad obecnej ortografii kazachskiej. Literę $h$, która jest spotykana $\mathrm{w}$ nielicznych zapożyczeniach arabskich, również można usunąc, zastępując ją litera $x$. Takie samo rozwiazanie można zastosować $\mathrm{w}$ stosunku do litery $u$, zastępujac ją litera $u$, a w razie potrzeby oddawać jej zmiękczenie poprzez zapis samogłoski. Kilka innych liter również można usunąć, doprowadzając liczbę liter alfabetu do 31. W taki sposób można usprawnić istniejący alfabet. Jako argumenty przeciwko zmianie alfabetu wymieniane sa $\mathrm{m}$.in. dyskomfort psychiczny obywateli kraju, utrata dziedzictwa kulturowego i duchowego, duże koszty, potencjalny analfabetyzm starszego pokolenia, które nie zna alfabetu łacińskiego. Poza tym sa obawy związane $z$ tym, że Kazachstan zrezygnuje $z$ języka rosyjskiego, który pełni funkcję lingua franca, czyli języka komunikacji międzyetnicznej. Władze kraju niejednokrotnie podkreślały, że zmiana alfabetu w języku kazachskim w żaden sposób nie wpłynie na pozycję języka rosyjskiego w Kazachstanie, ponieważ Kazachstan realizuje politykę językowa przewidująca równoległe funkcjonowanie trzech języków: kazachskiego, angielskiego i rosyjskiego.

Uważam, że Muchit-Ardager Sydyknazarow słusznie podkreśla to, że wykorzystywany do tej pory alfabet to quasi-cyrylica, a zastapienie jej quasi-łacinką może się okazać zbędną reformą, która niczego nie przyniesie. ${ }^{17}$ Te podstawowe cele, które przewiduje zmiana alfabetu na łaciński, nie będa spełnione, jeśli będzie to alfabet niefunkcjonalny ze znakami diakrytycznymi, niestosowanymi w międzynarodowej praktyce, a także znakami $z$ innego systemu alfabetycznego. Kazachstan, dążac do integracji ze społecznościa międzynarodową, chcąc odbudować swój kod kulturowy i zachować język kazachski, musi podejść do sprawy zmiany alfabetu maksymalnie rozsądnie, uwzględniajac wszystkie wady i zalety tej reformy. $Z$ pewnościa jest to bardzo kosztowna inicjatywa, ale opłacalna w perspektywie długoterminowej. Stawka jest nie tylko rozwój kraju, ale również tożsamość przyszłych pokoleń.

Argumentów „za” i „przeciw” jest wiele, ale pewne jest to, że proces przejścia zapisu języka kazachskiego na alfabet łaciński już się rozpoczął. Najważniejsze jest to, aby Kazachstan potrafił wykorzystać doświadczenie innych krajów, które zmieniły swój alfabet, i z maksymalną korzyścią dla kraju wdrożyć nowy alfabet.

16 A. Bahtovaršoev, Prognoz vozmožnyh posledstvij perehoda na latinskij alfavit $v$ Kazahstane, „Zhurnal Belorusskogo Gosudarstvennogo Universiteta. Sociologija" 2020, s. 71-77.

17 M. Sydyknazarov, Latinica $v$ Kazahstane: $v$ potoke istorii, portal informacyjny zebra.today, 27 września 2016 [dostęp: 14 lutego 2021]. Dostępny w Internecie: https://zebra.today/i364 


\section{Bibliografia}

A. Bahtovaršoev, 2020, Prognoz vozmožnyh posledstvij perehoda na latinskij alfavit $v$ Kazahstane, „Zhurnal Belorusskogo Gosudarstvennogo Universiteta. Sociologija" nr 1, s. 71-77.

E. Eliseeva, 2019, V Kazahstane vypustili $v$ obraščenie obnovlennye monety s nadpis'ju "QAZAQSTAN", gazeta „Kazahstanskaja Pravda” [dostęp: 14 lutego 2021]. Dostępny w Internecie: https://kazpravda.kz/news/ekonomika/v-kazahstane-vipustili-v-obrashchenie-obnovlennie-moneti-snadpisu-qazaqstan

D. Ešpanova, R. Kadyržanov, 2017, Perevod kazahskoj pis'mennosti na latinskuju grafiku glazami kazahstancev, „Al-Farabi. Journal of socio-humanitarian studiues" nr 4 (60), s. 15-24.

Zh. Habdulhabar, E. Kazistaev, 2019, Net digrafov, est' umlaut, brevis $i$ sedil'. Kak predlagajut menjat' novyj kazahskij alfavit na latinice, portal informacyjny informburo.kz [dostęp: 14 lutego 2021]. Dostępny w Internecie: https://informburo.kz/stati/net-digrafov-est-umlaut-brevis-i-sedil-kakpredlagayut-menyat-novyy-kazahskiy-alfavit-na-latinice.html

N. Nazarbaev, 2017, Memleket basshysynyñ „Bolashaqqa baǵdar: rýhanı jańǵyrý" atty maqalasy [dostęp: 14 lutego 2021]. Dostępny w Internecie: https://www.akorda.kz/kz/events/akorda_news/press_conferences/memleket-basshysynyn-bolashakka-bagdar-ruhani-zhangyru-atty-makalasy

N. Nazarbaev, 2012, Poslanie Prezidenta Respubliki Kazahstan - Lidera Nacii N.A.Nazarbaeva Narodu Kazahstana "Strategija „Kazahstan-2050": Novyj političeskij kurs sostojavšegosja gosudarstva” [dostęp: 14 lutego 2021]. Dostępny w Internecie: https://online.zakon.kz/m/document/?doc_ id=31305418\#sub_id=70300

M. Sydyknazarov, Esli delat' - tak čisto!, oficjalna strona Instytutu Językoznawstwa im. Achmeta Bajtursynuly [dostęp: 14 lutego 2021]. Dostępny w Internecie: https://tbi.kz/opinions

M. Sydyknazarov, 2016, Latinica $v$ Kazahstane: $v$ potoke istorii, portal informacyjny zebra.today [dostęp: 14 lutego 2021]. Dostępny w Internecie: https:// zebra.today/i364

Zh. Urankaeva, 2017, Predvaritel'nyj alfavit kazahskogo jazyka na latinice [dostęp: 14 lutego 2021]. Dostępny w Internecie: https://www.kazpravda.kz/ news/obshchestvo/predvaritelnii-alfavit-kazahskogo-yazika-na-latinitse

Činouniki stali otvečat' na obraščenija graždan na latinice, 2017, portal zakon. kz [dostęp: 14 lutego 2021]. Dostępny w Internecie: https://www.zakon. $\mathrm{kz} / 4886650$-chinovniki-stali-otvechat-na.html

Emle erejeleri, strona internetowa Narodowego centrum Naukowo-Praktycznego im. Sz. Szajachmetowa „Til-Qazyna” [dostęp: 14 lutego 2021]. Dostępny w Internecie: https://www.qazlatyn.kz/grammar

Kogda načnetsja perehod na novyj alfavit $v$ Kazahstane, 2021, gazeta „Kazahstanskaja Pravda" [dostęp: 14 lutego 2021]. Dostępny w Internecie:

https:/ / www.kazpravda.kz/news/obshchestvo/predstavlen-obnovlennii-alfavitkazahskogo-yazika-na-latinitse

Qazaq tili álipbiin kurilltsadan latyn grafikasyna kóshirý týraly, 2017, oficjalna strona Prezydenta Republiki Kazachstanu [dostęp: 14 lutego 2021]. Do- 
stępny w Internecie: https://www.akorda.kz/kz/legal_acts/decrees/kazaktili-alipbiin-kirillicadan-latyn-grafikasyna-koshiru-turaly

"Qazaq tili álipbiin kirilltsadan latyn grafikasyna kóshirý týraly" Qazaqstan Respýblıkasy Prezıdentinin 2017 jylǵy 26 qazandaǵy №569 Jarlyǵyna ózgeris engizý týraly, 2018 [dostęp: 14 lutego 2021]. Dostępny w Internecie: https:/ / www.akorda.kz/kz/legal_acts/decrees/kazak-tili-alipbiin-kirillicadan-latyngrafikasyna-koshiru-turaly-kazakstan-respublikasy-prezidentinin-2017zhylgy-26-kazandagy-569-zharlygy

Qazaqstan Respýblikasynyń memlekettik eltańbasy, oficjalna strona Prezydenta Republiki Kazachstanu [dostęp: 14 lutego 2021]. Dostępny w Internecie: https://www.akorda.kz/kz/state_symbols/kazakhstan_emblem

„Til-Qazyna” Respýblıkalyq aqparattyq-tanymdyq gazeti [dostęp: 14 lutego 2021]. Dostępny w Internecie: https:/ / gazet.tilqazyna.kz/pdf

Zakon Kazahskoj Sovetskoj Socialističeskoj Respubliki ot 22 sentjabrja 1989 goda O jazykah v Kazahskoj SSR [dostęp: 14 lutego 2021]. Dostępny w Internecie: https://online.zakon.kz/document/?doc_id=1005765\#pos=15;-116

\title{
Problems and prospects of the Kazakh language transitioning into the Latin alphabet
}

\begin{abstract}
Summary
This paper is dedicated to the issue of the Kazakh language transitioning into the Latin alphabet. It discusses the problems and prospects of the Kazakh language alphabet shifting from the Cyrillic alphabet to the Latin one. The author presents the history of the alphabets used in the Kazakh language (Arabic, Latin, Cyrillic), and chronologically presents the variants of the new alphabet as well as the results of social research and opinions of linguists.
\end{abstract}

Keywords: Kazakh language - Latin alphabet - Cyrillic alphabet - change of alphabet. 